Int. J. Dev. Biol. 57: 281-287 (2013)

doi: $10.1387 / \mathrm{ijdb} .130039$ sd

\title{
UV and genotoxic stress induce ATR relocalization in mouse spermatocytes
}

\author{
SARA DI SIENA ${ }^{1}$, FEDERICA CAMPOLO ${ }^{2}$, PELLEGRINO ROSSI ${ }^{2}$, EMMANUELE A. JANNINI ${ }^{3}$, \\ SUSANNA DOLCI*,2 and MANUELA PELLEGRINI ${ }^{4 *}$ \\ ${ }^{1}$ Department of SAIMLAL, University of Rome "La Sapienza", Rome, ${ }^{2}$ Department of Biomedicine and Prevention, University \\ of Rome "Tor Vergata", Rome, ${ }^{3}$ Department of Clinical and Applied Sciences and Biotechnologies, University of L'Aquila, \\ L'Aquila, Italy and ${ }^{4}$ Department of Medicine and Health Sciences, University of Molise, Campobasso, Italy
}

\begin{abstract}
During meiosis, phosphorylation of $\mathrm{H} 2 \mathrm{AX}$ is one of the earliest cellular responses to the generation of DNA double-strand breaks (DSBs) by the SP011 topoisomerase. ATM is the kinase which mediates the formation of phosphorylated H2AX ( $\gamma \mathrm{H} 2 \mathrm{AX})$ meiotic foci, while ATR is the kinase which signals chromosome asynapsis at the level of the $X Y$ bivalent. To investigate the possible role of ATR also in DNA damage signalling in meiotic cells, we studied the effect of UV radiation and chemotherapy drugs on H2AX phosphorylation and ATR relocalization in mouse pachytene spermatocytes. Here, we report that UV, a single strand break DNA-damaging agent, induces ATR relocalization from the $X Y$ sex body to nuclear foci and intense H2AX phosphorylation. Other DNA damage proteins such as MDC1, NBS1 and 53BP1 showed a similar relocalization following UVA microirradiation of spermatocytes. We found that DNA damage induced by UV increased the intensity and the number of $\gamma \mathrm{H} 2 \mathrm{AX}$ foci also in Atm null spermatocytes. Inhibition of RNA synthesis was found to induce the formation of $\gamma \mathrm{H} 2 \mathrm{AX}$ foci, but it did not influence the DNA damage response to UV irradiation. Finally, exposure of spermatocytes to double strand break DNA-damaging agents such as cisplatin, bleomycin or etoposide also induced ATR relocalization and intense H2AX phosphorylation and led to anomalies in synaptonemal assembly. Our results demonstrate that DNA damage induced by genotoxic stress can activate ATR and influence meiotic chromatin remodelling through $\mathrm{H} 2 \mathrm{AX}$ phosphorylation, likely as part of a response which normally ensures germ cell genomic integrity.
\end{abstract}

KEY WORDS: DNA damage, ATR, pachytene spermatocyte

\section{Introduction}

DNA damage activated pathways consist of three major groups of evolutionarily conserved proteins which are able to sense and to translate the signal of damaged DNA into cell cycle arrest and DNA repair responses. Sensor proteins can recognize damaged DNA directly or indirectly, while transducer proteins, typically phosphatidylinositol 3-kinase-like kinase family proteins (PIKKs) such as ATM, ATR and DNA-PK, relay and amplify the damage signal. Effector proteins control cell cycle progression, chromatin remodelling and DNA repair (Melo and Toczyski, 2002, Rouse and Jackson, 2002, Zhou and Elledge, 2000). One of the earliest event which activate the DNA damage pathways is the recruitment of damage-associated PIKKs to DNA lesions which leads to their activation and function in checkpoint signalling and DNA repair (Paull et al., 2000, Shiloh, 2003). DNA damage is often associated with phosphorylation of histone variant H2AX (Paull et al., 2000), generating a form of the protein referred to as $\gamma \mathrm{H} 2 \mathrm{AX}$, by one of the members of the PIKKs. Upon phosphorylation, mammalian $\gamma \mathrm{H} 2 \mathrm{AX}$ associates with organized and dynamic assemblies of damage response factors, such as NBS1, RAD51 and BRCA1, in supramolecular structures termed 'foci' (Carney et al., 1998, Paull et al., 2000). During meiosis, phosphorylation of H2AX by ATM is one of the earliest cellular responses to the formation of DNA double-strand breaks (DSBs) induced by the topoisomerase SPO11 (Bellani et al., 2005, Mahadevaiah et al., 2001). Diffused

Abbreviations used in this paper: DSB, DNAdouble-strand break; SSB, single strandbreak.

*Address correspondence to: Manuela Pellegrini. Department of Medicine and Health Sciences, University of Molise, Campobasso, Italy.

E-mails: manuela.pellegrini@unimol.it - dolci@uniroma2.it

Supplementary Material (one figure) for this paper is available at: http://dx.doi.org/10.1387/ijdb.130039sd

Final, author-corrected PDF published online: 5 June 2013.

ISSN: Online 1696-3547, Print 0214-6282

(c) 2013 UBC Press

Printed in Spain 
A

IP:

Fig. 1. H2AX is phosphorylated by ATR in vitro and in vivo. (A) In vitro ${ }^{32} P$-kinase assay was performed using anti-ATR or control IgG immunoprecipitates on recombinant GST-H2AX. Immunoprecipitates from pachytene spermatocytes were preincubated in the absence or presence of $10 \mathrm{mM}$ caffeine for $30 \mathrm{~min}$ at room temperature and then the assay was carried out by adding ${ }^{32} P-\gamma$ ATP to the reactions. The amount of immunoprecipitatedATR is shown. (B) Immunofluorescence analysis of $\gamma \mathrm{H} 2 \mathrm{AX}$ on pachytene spermato-

cytes cultured overnight and incubated for $2 \mathrm{~h}$ with $10 \mathrm{mM}$ caffeine before UV irradiation (200 mj/cm2). $\gamma H 2 A X$ staining in the sex body was also observed on spermatocytes cultured overnight with $10 \mathrm{mM}$ caffeine. Nuclei are stained with Hoechst (Blue).

foci of $\gamma \mathrm{H} 2 \mathrm{AX}$ characterize the preloptene/leptotene stages of meiosis while from zygotene to pachytene $\gamma \mathrm{H} 2 \mathrm{AX}$ becomes concentrated into the $X Y$ body, a condensed and transcriptionally inactive chromatin domain formed by $X$ and $Y$ chromosomes. It has been shown that the kinase ATR colocalizes with $\gamma \mathrm{H} 2 \mathrm{AX}$ and $B R C A 1$ within the $X Y$ body and that $B R C A 1$ is required for docking ATR to the sex body (Bellani et al., 2005, Tibbetts et al., 1999). It has been also suggested that every chromosome asynapsis can activate ATR and DNA damage response factors leading to $\gamma \mathrm{H} 2 \mathrm{AX}$ formation in the absence of DSBs at the late zygotene/early pachytene stage, in the sex body (Barchi et al., 2005). In addition to meiotic DSBs, germ cells might undergo DNA damage after exposure to genotoxic stress, such as radioand chemotherapy for cancer treatment. It has been shown that etoposide, an inhibitor of topoisomerase II, can induce clastogenic effects exclusively in meiotic spermatocytes (La Salle et al., 2009). To date it is still unknown whether ATM or ATR or both mediate DNA damage signalling induced by genotoxic stress in meiotic cells. It has been shown, however, that DSB induced by X-ray irradiation or etoposide can block meiotic progression (G2/MI) induced by the phosphatase inhibitor okadaic acid $(\mathrm{OA})$ in vitro
(Matulis and Handel, 2006).

In order to understand if ATR can play a role in DNA damage signalling of spermatocytes induced by genotoxic agents, we treated spermatocytes isolated in vitro with UV radiations or drugs which can induce SSB or DSB and monitored ATR activity and relocalization from the sex body to the whole nucleus.

\section{Results}

\section{ATR relocalizes in pachytene spermatocytes after DNA damage}

It has been extensively demonstrated that by the pachytene stage, ATR is exclusively localized within the asynapsed $X Y$ bivalent. To understand if in this nuclear localization ATR is active, we immunoprecipitated ATR from purified pachytene spermatocytes and then performed an in vitro kinase assay on GST-H2AX fusion protein as substrate. As shown in Fig. 1A, anti-ATR but not control IgGs immunoprecipitates induced GSTH2AX phosphorylation. Preincubation of the immunoprecipitates with $10 \mathrm{mM}$ caffeine completely inhibited GST-H2AX phosphorylation suggesting that ATR is active in pachytene spermatocytes. In mitotic cells ATR is activated by a broad spectrum of genotoxic agents that induce single strand breaks (SSBs, UV light) (Turner et al., 2005) or DSBs (Shiotani and Zou, 2009) (X-rays) leading to ATR relocalization (Tibbetts et al., 1999). To understand if DNA damage can induce ATR nuclear relocalization also in meiotic cells, we irradiated isolated spermatocytes with UV rays and analyzed ATR and $\gamma \mathrm{H} 2 \mathrm{AX}$ status by immunofluorescence. Supplementary Fig. 1 shows that UV irradiation caused an intense dose-dependent increase of $\gamma \mathrm{H} 2 \mathrm{AX}$ immunostaining in foci with a maximum effect at 200 mjoule/cm². At this dose, UV induced also ATR relocalization from the sex body throughout the nucleus (Fig. 2). Spermatocyte preincubation for two hours with $10 \mathrm{mM}$ caffeine, an inhibitor of PIKKs, prevented the formation of $\gamma \mathrm{H} 2 \mathrm{AX}$ foci (Fig. 1B), but did not affect ATR relocalization (Fig. 2). Inhibition by caffeine, however, did not reduce $\gamma \mathrm{H} 2 \mathrm{AX}$ positivity within the sex body, even after overnight incubation (Fig. 1B). To understand if also ATM might be involved in signalling UV induced SSBs in spermatocytes, we investigated $\gamma \mathrm{H} 2 \mathrm{AX}$ in Atm-/- germ cells. We first evaluated the status of H2AX phosphorylation in mutant testes by immunofluorescence analysis on frozen sections. As expected, meiotic germ cells within testis tubules were arrested at the leptotene stage and showed intense $\gamma \mathrm{H} 2 \mathrm{AX}$ staining within the whole nucleus(Fig. 3A). When isolated Atm-/-spermatocytes were subjected to UV irradiation, we observed an increase of $\gamma \mathrm{H} 2 \mathrm{AX}$ staining in foci within the whole nucleus. ATR staining was diffuse throughout the nucleus without evident difference both in control and UV treated spermatocytes.

In somatic cells, several DNA repair factors have been shown to colocalize following laser-induced DNA damage into $\gamma \mathrm{H} 2 \mathrm{AX}$ foci (Celeste et al., 2003). Among these, MDC1, NBS1 and 53BP1 
have been demonstrated to localize to the sex body of pachytene spermatocytes (Ahmed et al., 2007, Barchi et al., 2005). We found that all these proteins relocalize within the $\gamma \mathrm{H} 2 \mathrm{AX}$ foci in pachytene spermatocytes after UV microirradiation (Fig. 4 A-C).

\section{Inhibition of RNA synthesis induces the formation of $\gamma \mathrm{H} 2 \mathrm{AX}$ foci in pachytene spermatocytes}

To understand if RNA new synthesis was required for DNA damage signalling, we cultured pachytene spermatocytes for $15 \mathrm{hrs}$ in the presence of $5 \mu \mathrm{g} / \mathrm{ml}$ actinomycin D, an inhibitor of RNA polymerase II. Unexpectedly, we found that actinomycin D treatment induced the formation of $\gamma \mathrm{H} 2 \mathrm{AX}$ foci within the nucleus without affecting the $\gamma \mathrm{H} 2 \mathrm{AX}$ positivity within the sex vesicle (Fig. 5). On the other hand, ATR immunostaining was not consistently modified. Likewise actinomycin $D$ did not influence the nuclear relocalization of ATR nor the increase in $\gamma \mathrm{H} 2 \mathrm{AX}$ staining induced in spermatocytes by UV irradiation.

\section{A}
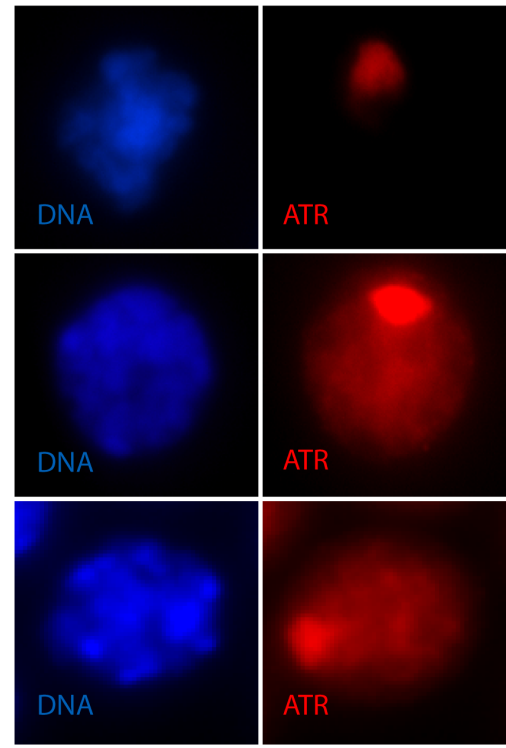

control

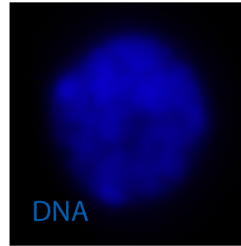

UV-200 $\mathrm{mj} / \mathrm{cm}^{2}$ $15 \mathrm{~min}$

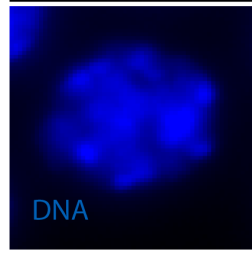

control

UV-200 $\mathrm{mj} / \mathrm{cm}^{2}$ $15 \mathrm{~min}$

B
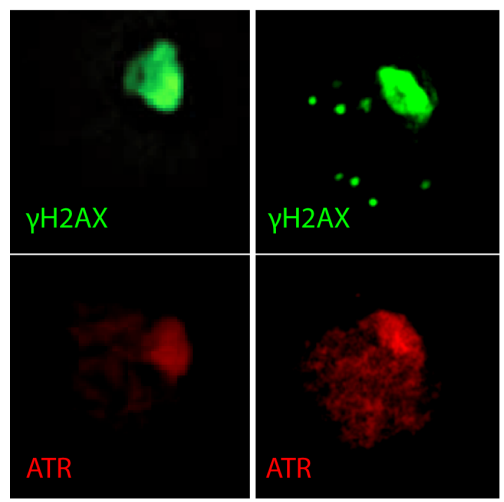

UV-200mj/ $/ \mathrm{cm}^{2}$ $10 \mathrm{mM}$ caffeine $2 \mathrm{~h}$

Fig. 2. UV irradiation induces ATR relocalization into the nucleus of pachytene spermatocytes. (A) Spermatocytes were exposed to UV irradiation at the indicated doses. $15 \mathrm{~min}$ after irradiation cells were fixed and immunodecorated for ATR. (B) same as A but cells were co-stained for $\gamma \mathrm{H} 2 \mathrm{AX}$ and ATR and analyzed by microscopic deconvolution.
A
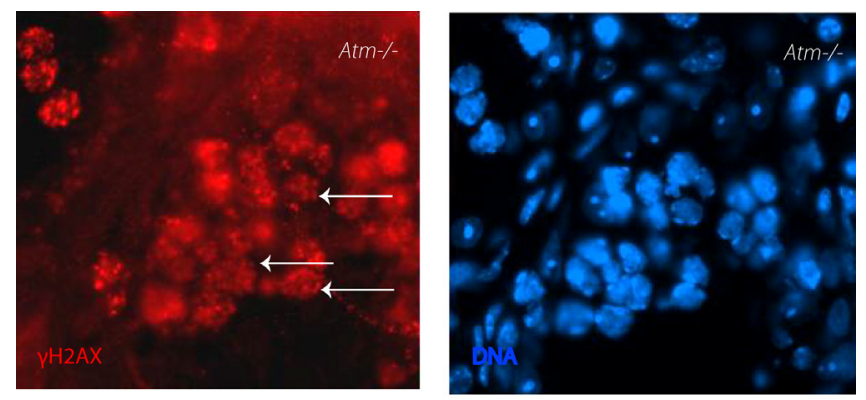

B

control
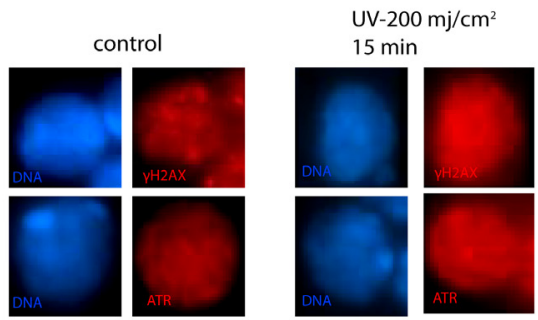

Fig. 3. ATR relocalizes in Atm $^{-/}$germ cells. (A) $\gamma \mathrm{H} 2 \mathrm{AX}$ immunolocalization on Atm-/-frozen section of adult testis. White arrows point to meiotic spermatocytes. (B) $\gamma H 2 A X$ (upper panels) and ATR (lower panels) immunolocalizations on untreated Atm ${ }^{*}$ pachytene spermatocytes (left panels) or after UV irradiation (right panel). Nuclei are stained with Hoechst (blue).

\section{DNA damage caused by chemotherapic compounds is as- sociated to ATR relocalization}

We next investigated if other genotoxic agents such as chemotherapy drugs, which are known to induce DSBs, could promote $\mathrm{H} 2 \mathrm{AX}$ phosphorylation and ATR relocalization in pachytene spermatocytes. We chose bleomycin, cisplatin and etoposide since these drugs are commonly used for the treatment of testicular cancers (Cavallo et al., 2012, de Wit et al., 2001). Cisplatin and bleomycin induce DNA DSBs by directly binding to DNA, while etoposide does it indirectly, by inhibiting the activity of the topoisomerase II enzyme. Cells were incubated for $15 \mathrm{hrs}$ in the presence or absence of each drug and then subjected to immunofluorescence analysis for $\gamma \mathrm{H} 2 \mathrm{AX}$ and ATR. To verify if the chromosome structure was affected by these treatments we used spermatocyte cytospread preparation in which double staining for the synaptonemal complex protein SCP3 and $\gamma \mathrm{H} 2 \mathrm{AX}$ was performed. As shown in Fig. 6A, bleomycin and cisplatin treatments at a concentration of $5 \mathrm{mg} / \mathrm{ml}$ and $40 \mu \mathrm{M}$, respectively, did not alter the chromosome structure. At the same time, the drugs induced foci formation and diffuse $\gamma \mathrm{H} 2 \mathrm{AX}$ staining while ATR staining was redistributed throughout the nucleus outside the sex body (Fig. 6A, B). Etoposide treatment $(40 \mu \mathrm{M})$ resulted in a partial synaptonemal axes disassembly as shown by the fragmentation of SCP3 staining pattern (Fig. 6A) and deeply impacted on chromatin structure by inducing a strong spread of $\gamma \mathrm{H} 2 \mathrm{AX}$ positivity and massive nuclear ATR relocalization (Fig. 6B). Western blot analysis confirmed that all drug treatments induced a strong increase of $\gamma \mathrm{H} 2 \mathrm{AX}$ levels, while ATR levels did not significantly change (Fig. 6C).

Since etoposide treatment prevents chromosome condensation of pachytene spermatocytes induced by okadaic acid (La Salle et al., 2009) (OA, an inhibitor of phosphatase PP2A), we investigated if also bleomycin and cisplatin, which act differently from etoposide in inducing DSBs, could inhibit meiotic chromosome condensa- 
A
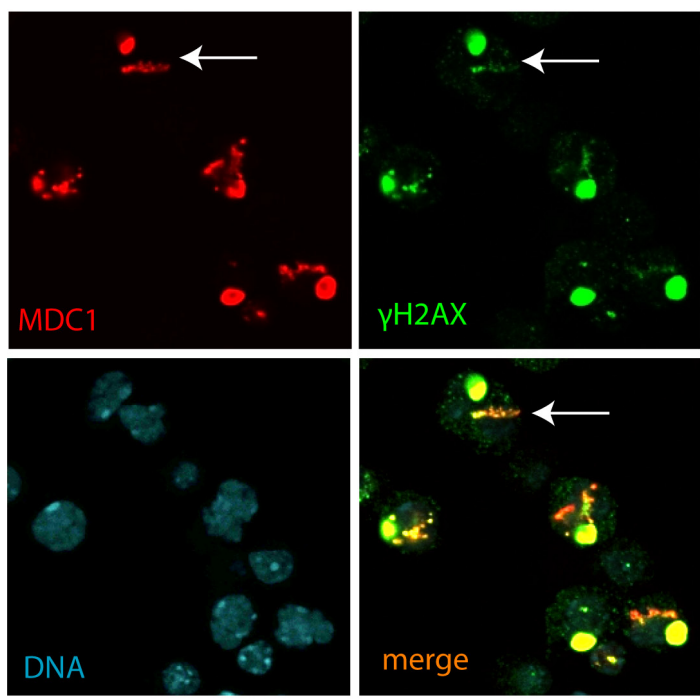

B
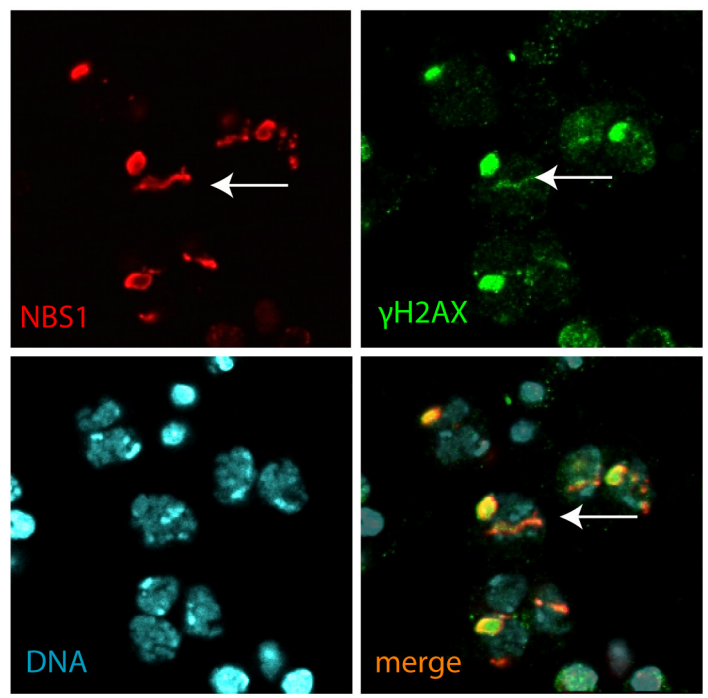

C
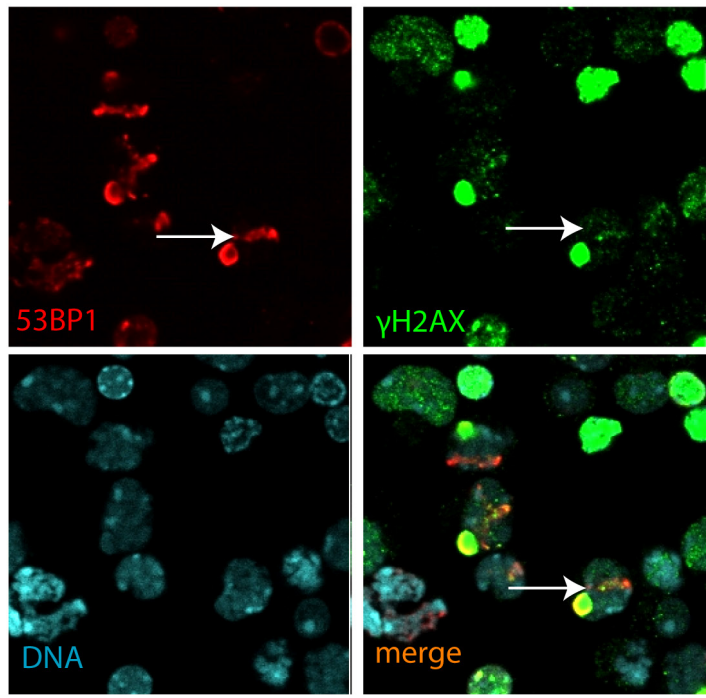

Fig. 4. UVA microirradiation induces MDC1, NBS1 and 53BP1 laser scissors relocalization. Spermatocytes were exposed to UVA microirradiation and after 8 min of recovery cells were fixed and immunodecorated for (A) MDC1, (B) NBS1 or (C) 53BP1 and $\gamma H 2 A X$
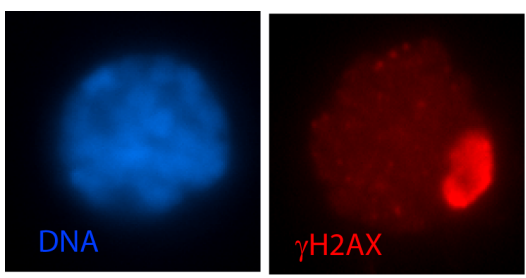

actinomycinD
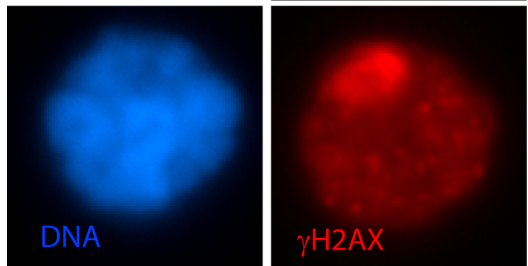

$U V+$ actinomycinD
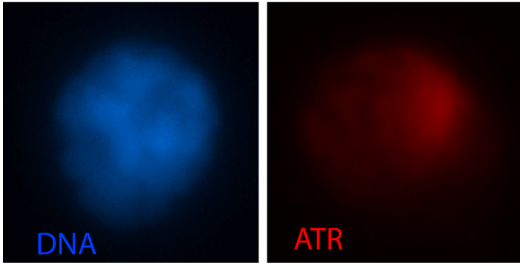

actinomycinD
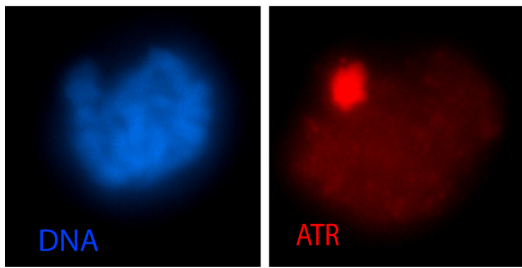

UV+ actinomycinD

Fig. 5. RNA transcription inhibition activates DNA damage signalling Immunostaining for $\gamma \mathrm{H} 2 \mathrm{AX}$ and ATR on isolated pachytene spermatocytes preincubated with $5 \mu \mathrm{g} / \mathrm{ml}$ actinomycin D and treated with UV irradiation (200 mj/cm2). Nuclei are counterstained with Hoechst.

tion. Control and treated spermatocytes were cultured for $5 \mathrm{hrs}$ with $\mathrm{OA}$ and then subjected to chromatin spreads and Giemsa staining. As expected, about $65 \% \pm 4 \%$ (mean \pm standard error) of control cells underwent chromosome condensation and nuclei showed correct metaphase I bivalents after OA treatment (Fig. 6D). On the contrary, the percentage of cells with normal metaphase I bivalents decreased to $30 \% \pm 5 \%$ and $30 \% \pm 3 \%$ showed broken chromosomes after bleomycin treatment (Fig. 6E). Similarly to bleomycin, cisplatin treatment induced the formation of broken condensed chromosomes in about $15 \% \pm 4.5 \%$ of cells, while normal metaphase I bivalents was reduced to $45 \% \pm 5.5 \%$ (Fig. 6F). Etoposide completely inhibited OA-induced chromosome condensation, as previously reported (La Salle et al., 2009) (Fig. 6G).

\section{Discussion}

Meiotic germ cells are physiologically exposed to DNA damage early during meiotic prophase by the activity of the DSB producing enzyme SPO11 (Bellani et al., 2005, Pellegrini et al., 2011). ATM is the PI3K-related kinase which mediates signalling of DNA damage during meiosis, while the PIK-kinase ATR, has been suggested to signal chromosome asynapsis during the late zygotene/early pachytene stage leading to $\gamma \mathrm{H} 2 \mathrm{AX}$ formation also in the absence of DSBs (Barchi et al., 2005). Although ATR associates to asynapsed chromosomes and to the sex body in pachytene spermatocytes, it is not clear whether it directly phosphorylates H2AX in these cells. 
By immunoprecipitation we demonstrate that at least in vitro ATR isolated from pachytene spermatocytes can phosphorylate $\mathrm{H} 2 \mathrm{AX}$ and that this reaction is inhibited by caffeine. Interestingly, we found that H2AX phosphorylation at the level of the sex body was not inhibited by caffeine suggesting that ATR may not be the kinase which phosphorylates $\mathrm{H} 2 \mathrm{AX}$ within the sex body or that this is a stable post-translational modification. Further experiments using cre/lox system will be useful to clarify this issue. UV irradiation is known to activate ATR signalling in mitotic cells (Wright et al., 1998). We found that this stress can activate ATR also in meiotic cells, as monitored by the formation of $\gamma \mathrm{H} 2 \mathrm{AX}$ foci and its nuclear relocalization. Despite the nuclear redistribution of $A T R$, we did not observe ATR relocalization into foci, perhaps because the signal was covered by the intense nucleoplasmatic staining. However we

A
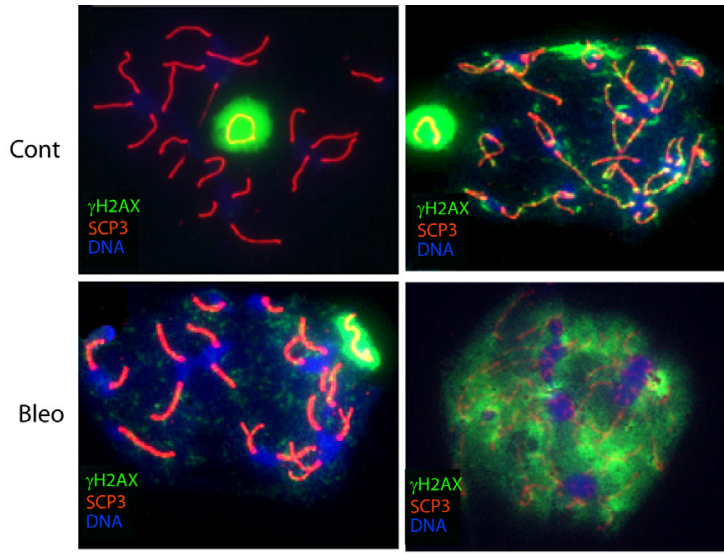

Cis

B
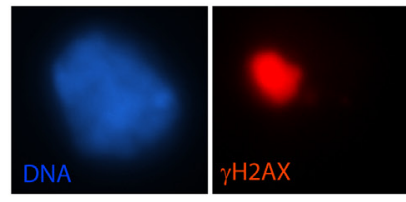

Cont
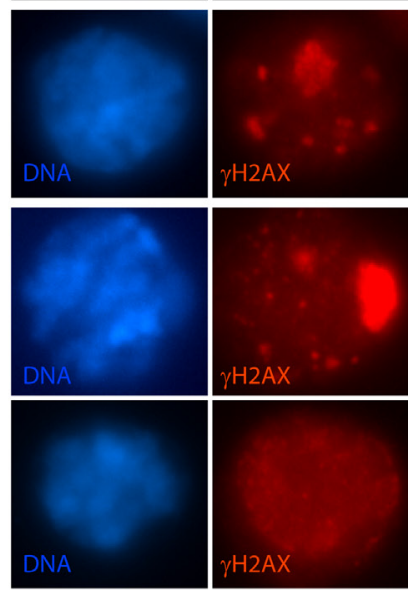

Bleo
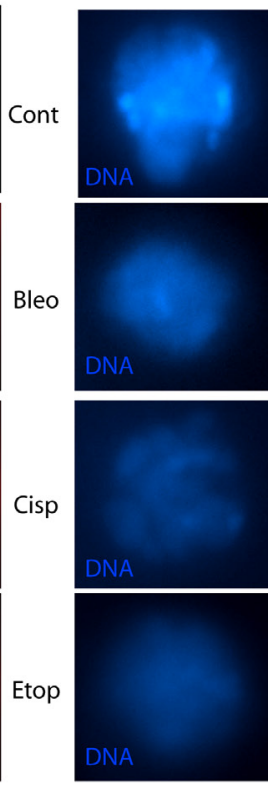

C

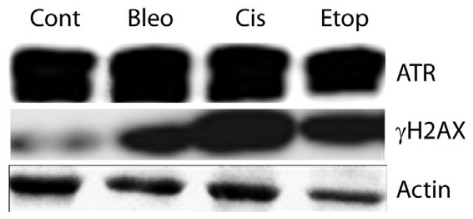

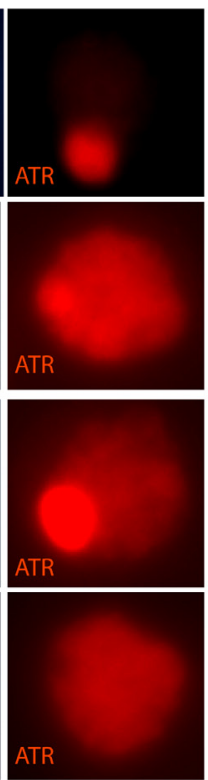

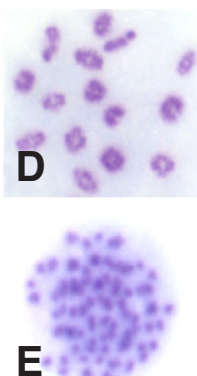

E

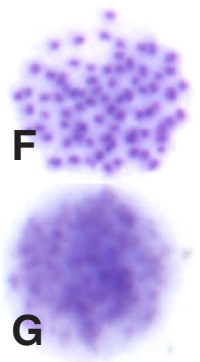

found that MDC1, NBS1 and 53BP1 relocalize to the site of DNA damage induced by laser scissors, as shown by the foci formed by the UV laser microirradiation, in agreement with the results obtained in somatic cells (Celeste et al., 2003). In line with the observations that $A t m-/$ - spermatocytes are positive for $\gamma \mathrm{H} 2 \mathrm{AX}$ (Tibbetts et al., 1999), we found that Atm null germ cells were intensively stained for $\gamma \mathrm{H} 2 \mathrm{AX}$. After UV irradiation meiotic nuclei showed a stronger positivity for H2AX phosphorylation, compared to non-irradiated cells, further indicating that ATR can be specifically activated by UV in such cells. Caffeine treatment inhibited UV-induced foci in wt spermatocytes, however ATR relocalization was only slightly reduced, suggesting that DNA damage monitoring activity of ATR, analogously to ATM (Daniel et al., 2012), is independent of its kinase activity. It has been shown that actinomycin $D$ treatment can

induce $\gamma \mathrm{H} 2 \mathrm{AX}$ foci in HeLa cells possibly through DNA-PK activation (Mischo et al., 2005). As for mitotic cells, we found that RNA synthesis inhibition induced the formation of DNA damage foci, suggesting that RNA polymerase II stall triggers DNA damage signalling. ATR localization was not significantly affected by actinomycin $\mathrm{D}$, indicating that another PIK-kinase, possibly DNA-PK, might be involved in $\mathrm{H} 2 \mathrm{AX}$ phosphorylation. It is important to underscore that the sex body chromatin, which is $\gamma \mathrm{H} 2 \mathrm{AX}$ positive, has been shown to be transcriptionally inactive. RNA synthesis inhibition, however, did not affect UV-induced DNA damage signalling since the increased $\gamma \mathrm{H} 2 \mathrm{AX}$ positivity after UV irradiation was not modified by actinomycin $D$. It has been shown that ATR recruitment onto $X Y$ chromatin is mediated by BRCA1 (Bellani et al., 2005), since the majority of spermatocytes carrying a deleted form of BRCA1 (BRCA1 ${ }^{\Delta 11}$ ) do not form the sex body and show mislocalization of ATR (Ward et al., 2004). We found that UV irradiation induces ATR relocalization from the sex body throughout the nucleus, suggesting that its nuclear relocalization can be mediated by BRCA1 following DNA damage also in meiotic cells. The lack of commercial working antibodies against BRCA1 make this hypothesis difficult to test.

It has been shown that sperm of mice treated

Fig. 6. Chemotherapy drugs induce ATR relocalization and chromosome fragmentation. (A) Chromosome Spreads on untreated pachytene spermatocytes and after 15 hours treatment with $40 \mu \mathrm{M}$ Cisplatin, $5 \mathrm{mg} / \mathrm{ml}$ Bleomycin and $40 \mu \mathrm{M}$ Etoposide following staining for $\gamma \mathrm{H} 2 \mathrm{AX}$ (green), SCP3 (red) and DAPI (blue). (B) Immunostaining for $\gamma \mathrm{H} 2 \mathrm{AX}$ (left panels) and ATR (right panels) on untreated pachytene spermatocytes or after 15 hours treatment with $40 \mu \mathrm{M}$ Cisplatin, $5 \mathrm{mg} / \mathrm{ml}$ Bleomycin and $40 \mu \mathrm{M}$ Etoposide. Nuclei are stained with Hoechst. (C) Western Blotting analysis on protein extracts from untreated pachytene spermatocytes or after genotoxic agents treatment $(40 \mu \mathrm{M}$ Cisplatin, $5 \mathrm{mg} / \mathrm{ml}$ Bleomycin and $40 \mu \mathrm{M}$ Etoposide) probed for ATR and phosphorylated H2AX. Actin was used as normalizer. (D-G) Images of air-dried and Giemsa-stained OA-treated chromatin from controlspermatocytes before(D) and after Bleomycin(E), Cisplatin (F) and Etoposide (G) treatment. 
with chemotherapy drugs carry chromosomal aberrations (partial duplications and deletions). It has been also shown that ATR kinase activity is induced in response to cisplatin (Damia et al., 2001, Yazlovitskaya and Persons, 2003) and etoposide (Rossi et al., 2006) in human cancer cell lines. We found that these drugs induce $\mathrm{H} 2 \mathrm{AX}$ phosphorylation, ATR relocalization in meiotic spermatocytes and chromosomal fragmentation, suggesting that ATR can participate in the formation of DNA damage foci in response to chemotherapy drugs in germ cells.

In conclusion, our findings showing that meiotic cell exposure to DNA-damage agents extend the results obtained in somatic cells and offer the first evidence that ATR may act in response to genomic damage also in germ cells.

\section{Materials and Methods}

\section{Germ cell preparation, cell culture and treatments}

Testes from adult CD1 mice (Charles River, Italy) or Atm-/-mutants (kindly gifted by Dr. Nussenzweig, NIH, USA) were used to prepare germ cells. Germ cells at pachytene spermatocyte stage were obtained by elutriation of the unfractionated single cell suspension as previously described (Grabske et al., 1975). Homogeneity of pachytene spermatocytes populations was about $80-85 \%$, and was routinely monitored morphologically. After elutriation, pachytene spermatocytes were cultured in MEM, supplemented with $0.5 \%$ bovine serum albumin (BSA), $1 \mathrm{mM}$ sodium pyruvate, $2 \mathrm{mM}$ sodium lactate, in six-well dishes at a density of $10^{6} \mathrm{cells} / \mathrm{ml}$ at $32^{\circ} \mathrm{C}$ in a humified atmosphere containing $95 \%$ air and $5 \% \mathrm{CO}_{2}$. Cells were preincubated for 2-12 hrs prior to treatments with the inhibitor Caffeine, at a concentration of $10 \mathrm{mM}$, or with an equal volume of DMEM (caffeine solvent). Actinomycin D (Sigma-Aldrich) was used at $5 \mu \mathrm{g} / \mathrm{ml}$ for $15 \mathrm{hrs}$ of incubation. For UV treatment, treated cells were adhered onto poly-L-lysine coated slides and irradiated using a UV Stratalinker (Stratagene) at the specified dosage. For cytological and immunofluorescence analyses, aliquots of the same samples were taken and processed as described below. For UV microirradiation, cells were adhered onto poly-L-lysine slides which were then mounted in the microscope stage of an LSM 3100 microscope (Leica, Bannockburn, IL) and treated with a 337.1-nm laser along a user-defined path. After laser treatment, cells were allowed to recover for $8 \mathrm{~min}$ or $4 \mathrm{hrs}$ at $37^{\circ} \mathrm{C}$ and were subsequently fixed with cold methanol for $15 \mathrm{~min}$ at $-20^{\circ} \mathrm{C}$ and processed for immunofluorescent staining.

\section{Western blot analysis}

Solubilized proteins were boiled for 5 minutes in SDS-PAGE sample buffer [62.5 mM Tris-HCl, pH 6.8, 10\% glycerol, 2\% (w/v) SDS, $0.7 \mathrm{M}$ 2-mercaptoethanol, and $0.0025 \%$ (w/v) bromophenol blue], and resolved on $10 \%$ or $15 \%$ SDS-polyacrylamide gel electrophoresis. Resolved proteins were transferred onto polyvinylidene difluoride membranes (Millipore). Membranes were then saturated with $5 \%$ nonfat dry milk in PBS for 1 hour at room temperature and incubated with the primary antibody diluted in PBS $/ 5 \%$ BSA overnight at $4^{\circ} \mathrm{C}$ (goat polyclonal anti-ATR sc-N19, Santa Cruz, 1:1000 dilution; rabbit anti-actin, Sigma-Aldrich, 1:3000 dilution; rabbit anti- $\gamma \mathrm{H} 2 \mathrm{AX}$, Upstate, rabbit polyclonal, 1:2000 dilution). Secondary antibody conjugated to horseradish peroxidase was incubated with the membranes for 1 hour at room temperature. Bands were detected by chemiluminescent method (Santa Cruz).

\section{Immunofluorescence analyses}

Frozen sections from adult testes from wt animals, Atm -/- mutants were prepared using a microtome and placed on glass slides. Control or treated spermatocytes were spotted on poly-L-lysine coated glass slides and fixed at room temperature for 15 minutes in $4 \%$ paraformaldehyde. Cells and tissues were permeabilized for 10 minutes in $0.1 \%$ TritonX-100 and blocked for 1 hour in PBS with 5\% BSA. After three washes in PBS, cells were incubated over night at $4^{\circ} \mathrm{C}$ with mouse monoclonal anti-ATR
(Cell Signalling, rabbit polyclonal, 1:100 dilution), or rabbit anti $\gamma \mathrm{H} 2 \mathrm{AX}$ (1:400 dilution), as primary antibodies. After five washes in PBS, cells were incubated for 1 hour at $37^{\circ} \mathrm{C}$ with cyanine3-conjugate goat anti-rabbit IgG (Calbiochem, 1:300 dilution) and cyanine3-conjugate rabbit anti-goat IgG (Santa Cruz sc-2094, 1:400 dilution). Rabbit anti-Nbs1 was from dr. A. Nussenzweig, rabbit anti-53BP1 was from dr. J. Chen, and mouse anti-MDC1 was from Millipore. To stain DNA, Hoechst 33258 dye (SigmaAldrich) was added for the last 10 minutes at a final concentration of 0.1 $\mathrm{mg} / \mathrm{ml}$. Cells were washed extensively in PBS and slides were mounted in $50 \%$ glycerol in PBS.

\section{Glutathione S-transferase (GST)-H2AX fusion protein synthesis and purification}

h2ax cDNA was generated by RT-PCR from total spermatocyte RNA and cloned as GST-fusion in BamH1-EcoRI cloning site of pGEX-4X (Pharmacia). Escherichia coli cells (BL21) transformed with pGEX-4X-H2AX construct were grown at $30^{\circ} \mathrm{C}$ in LB medium to an optical density (O.D. $600 \mathrm{~nm}$ ) of 0.5 . Expression of recombinant proteins was induced by the addition of $0.5 \mathrm{mM}$ isopropyl-1-thio- $\beta$-galactopyranoside for 4 hours at the same temperature. Cells were harvested and lysed in phosphate-buffered saline (PBS) containing $0.1 \%$ Triton X-100, 1 mM DTT, protease inhibitors, by sonication (three cycles of 1 minute each). Bacterial extracts were clarified by centrifugation at $12.000 \mathrm{rpm}$ and supernatant fractions were incubated with glutathione-Sepharose beads (Sigma, G 4510) for 1 hour at $4^{\circ} \mathrm{C}$ with constant shaking. After several washes in PBS, proteins were eluted with $50 \mathrm{mM}$ Tris- $\mathrm{HCl} \mathrm{pH} \mathrm{8,} \mathrm{containing} 10 \mathrm{mM}$ glutathione (Sigma Aldrich, G 4251) and $1 \mathrm{mM}$ DTT. Purified proteins were stored at $-80^{\circ} \mathrm{C}$ in the same buffer containing $10 \%$ glycerol.

\section{Immunoprecipitation analysis}

Pachytene spermatocytes ( $3 \times 10^{6}$ cells) were homogenized in lysis buffer (25 mM Hepes, pH 7.5, $100 \mathrm{mM} \mathrm{NaCl}, 20 \mathrm{mM} \beta$-glicerophosphate, $15 \mathrm{mM}$ EGTA, $15 \mathrm{mM} \mathrm{MgCl}, 0.1 \mathrm{mM}$ sodium orthovanadate, $1 \mathrm{mM}$ DTT, $10 \mu \mathrm{g} /$ $\mathrm{ml}$ leupeptin and $10 \mu \mathrm{g} / \mathrm{ml}$ aprotinin, $1 \mathrm{mMPMSF}$ ), sonicated and extracts were collected after centrifugation at $15.000 \mathrm{rpm}$ for 10 minutes at $4^{\circ} \mathrm{C}$. For immunoprecipitation, $300 \mu \mathrm{g}$ of total proteins were precleared with goat IgG-linked protein G-Sepharose beads (Sigma Aldrich) for 30 min at $4^{\circ} \mathrm{C}$, under constant shaking. One $\mu \mathrm{g}$ of goat polyclonal anti-ATR, or IgGs were added to the precleared extracts and incubated for $2 \mathrm{hr}$ and then added to protein G-Sepharose beads and incubated for one additional hour under constant shaking at $4^{\circ} \mathrm{C}$. At the end of the incubation, sepharose beadsbound immunocomplexes were rinsed three times with PBS and eluted in SDS-sample buffer for western blot analysis, or washed twice with the kinase buffer for immunokinase assay.

\section{Immunokinase assay}

Immunocomplexes bound to sepharose beads obtained from immunoprecipitation of cell extracts were rinsed twice with ATR-kinase buffer (50 mM Hepes, pH7.5, 5 mM $\beta$-glicerophosphate, 2 mM EGTA, $15 \mathrm{mM}$ $\mathrm{MgCl}_{2}, 5 \mathrm{mM} \mathrm{MnCl}_{2}, 0.1 \mathrm{mM}$ sodium orthovanadate, $1 \mathrm{mM} \mathrm{DTT}, 10 \mu \mathrm{g} / \mathrm{ml}$ leupeptin and $10 \mu \mathrm{g} / \mathrm{ml}$ aprotinin). Pellets were then pre-incubated in the presence or absence of $10 \mathrm{mM}$ caffeine at room temperature for $30 \mathrm{~min}$ to inhibit ATR activity. At the end of the preicubation, $10 \mu \mathrm{M}{ }^{32} \mathrm{P} \gamma \mathrm{ATP}(0.2 \mu \mathrm{Ci} /$ $\mu \mathrm{l}), 1 \mu \mathrm{g}$ cAMP-dependent protein kinase inhibitor and $1 \mu \mathrm{g}$ GST-H2AX as substrate were added to the kinase buffer. Reactions were carried on in a total volume of $25 \mu \mathrm{l}$ for 20 minutes at $30^{\circ} \mathrm{C}$. Supernatants were stopped by adding SDS-sample buffer, boiled and separated on SDS-PAGE and the dried gel exposed to autoradiography.

\section{Cytospreads}

Cytospreads were prepared as previously described (Pellegrini et al., 2010). Briefly, germ cells were re-suspended in $200 \mu \mathrm{l}$ of $0.5 \% \mathrm{NaCl} \mathrm{pH} 8$ and left on ice for $5 \mathrm{~min}$. Cell suspension was spotted on $6 \mathrm{~mm}$-well glass slides and nuclei were allowed to deposit for 10min at RT. Nuclei were then fixed in $10 \mathrm{ml}$ of $2 \%$ PFA and $0.033 \mathrm{mg} / \mathrm{ml} \mathrm{SDS}$ for $6 \mathrm{~min}$ and for further 6 
$\min$ in $2 \%$ PFA. Slides were then rinsed three times in washing buffer $(0.4 \%$ Photo-Flo, Kodak) for $3 \mathrm{~min}$, air dried at RT for $10 \mathrm{~min}$ and processed for immunostaining or stored at $-80^{\circ} \mathrm{C}$ for up to 2 months. Primary antibodies, mouse anti- $\gamma \mathrm{H} 2 \mathrm{AX}(1: 3000, \mathrm{Abcam}, \mathrm{ab}-26350)$ and rabbit anti-SCP3 (1:1000, Novus Biologicals, NB300-231), diluted in ADB buffer (10\% goat serum, $3 \%$ BSA, $0.05 \%$ Triton $X-100$, in PBS) were incubated over night at $37^{\circ} \mathrm{C}$. Secondary antibodies (Alexa) were diluted 1:200 in ADB buffer and incubated for $1 \mathrm{~h}$ at $37^{\circ} \mathrm{C}$. Slides were mounted (ProLong Gold $\AA$ antifade -Molecular Probes) and analysed on a Leica CTR6000 microscope equipped with a deconvolution imaging software.

\section{Metaphase spreads}

After treatment with OA ( $5 \mu \mathrm{M}$, Calbiochem) for $5 \mathrm{~h}$, pachytene spermatocytes were incubated in a hypotonic solution $(\mathrm{KCl} 75 \mathrm{mM})$ for 30 minutes at $37^{\circ} \mathrm{C}$. Cells were then fixed in a freshly-made cold mixture of 3:1 methanol: acetic acid for 1 hour at $4^{\circ} \mathrm{C}$, washed twice with the same solution and resuspended in at least $200 \mu \mathrm{l}$ of cold fixative. $20 \mu \mathrm{l}$ of cell suspension were dropped onto a slide and allowed to air dry. Spreads were then stained with Giemsa solution (1:20, Sigma Aldrich), mounted and analysed at the microscope.

\section{Acknowledgments}

We thank dr. A. Nussenzweig (NIH, Bethedsa, USA) for the UV microdissection facility and for providing Nbs1 antibodies and Atm null mice, dr. J. Chen (Mayo Clinic, Rochester, USA) for providing 53BP1 antibodies, and dr. M. Barchi (University of Rome Tor Vergata, Italy) for advice in chromatin spread preparation. This work was supported from the Italian Ministry by University (Prin 20084XRSBS_004, Prin 2009FW5SP3_001, Firb RBAP109BLT_004).

\section{References}

AHMED, E.A., VAN DER VAART, A., BARTEN, A., KAL, H.B., CHEN, J., LOU, Z., MINTER-DYKHOUSE, K., BARTKOVA, J., BARTEK, J., DE BOER, P. et al., (2007). Differences in DNA double strand breaks repair in male germ cell types: lessons learned from a differential expression of Mdc1 and 53BP1. DNA Repair (Amst) 6: 1243-1254.

BARCHI, M., MAHADEVAIAH, S., DI GIACOMO, M., BAUDAT, F., DE ROOIJ, D.G. BURGOYNE, P.S., JASIN, M. and KEENEY, S. (2005). Surveillance of different recombination defects in mouse spermatocytes yields distinct responses despite elimination at an identical developmental stage. Mol Cell Biol 25: 7203-7215.

BELLANI, M.A., ROMANIENKO, P.J., CAIRATTI, D.A. and CAMERINI-OTERO, R.D. (2005). SPO11 is required for sex-body formation, and Spo11 heterozygosity rescues the prophase arrest of Atm-/-spermatocytes. J Cell Sci 118: 3233-3245.

CARNEY, J.P., MASER, R.S., OLIVARES, H., DAVIS, E.M., LE BEAU, M., YATES, J.R., 3RD, HAYS, L., MORGAN, W.F. and PETRINI, J.H. (1998). The hMre11/ hRad50 protein complex and Nijmegen breakage syndrome: linkage of doublestrand break repair to the cellular DNA damage response. Cell 93: 477-486.

CAVALLO, F., GRAZIANI, G., ANTINOZZI, C., FELDMAN, D.R., HOULDSWORTH, J., BOSL, G.J., CHAGANTI, R.S., MOYNAHAN, M.E., JASIN, M. and BARCHI, M. (2012). Reduced proficiency in homologous recombination underlies the high sensitivity of embryonal carcinoma testicular germ cell tumors to Cisplatin and poly (adp-ribose) polymerase inhibition. PLoS One 7: e51563.

CELESTE, A., FERNANDEZ-CAPETILLO, O., KRUHLAK, M.J., PILCH, D.R., STAUDT, D.W., LEE, A., BONNER, R.F., BONNER, W.M. and NUSSENZWEIG, A. (2003). Histone H2AX phosphorylation is dispensable for the initial recognition of DNA breaks. Nat Cell Biol 5: 675-679.

DAMIA, G., FILIBERTI, L., VIKHANSKAYA, F., CARRASSA, L., TAYA, Y., D'INCALCI, M. and BROGGINI, M. (2001). Cisplatinum and taxol induce different patterns of p53 phosphorylation. Neoplasia 3: 10-16.

DANIEL, J.A., PELLEGRINI, M., LEE, B.S., GUO, Z., FILSUF, D., BELKINA, N.V.,
YOU, Z., PAULL, T.T., SLECKMAN, B.P., FEIGENBAUM, L. et al., (2012). Loss of ATM kinase activity leads to embryonic lethality in mice. J Cell Biol 198: 295-304.

DE WIT, R., ROBERTS, J.T., WILKINSON, P.M., DE MULDER, P.H., MEAD, G.M., FOSSA, S.D., COOK, P., DE PRIJCK, L., STENNING, S. and COLLETTE, L. (2001). Equivalence of three or four cycles of bleomycin, etoposide, and cisplatin chemotherapy and of a 3- or 5-day schedule in good-prognosis germ cell cancer: a randomized study of the European Organization for Research and Treatment of Cancer Genitourinary Tract Cancer Cooperative Group and the Medical Research Council. J Clin Oncol 19: 1629-1640.

GRABSKE, R.J., LAKE, S., GLEDHILL, B.L. and MEISTRICH, M.L. (1975). Centrifugal elutriation: separation of spermatogenic cells on the basis of sedimentation velocity. J Cell Physiol 86: 177-189.

LA SALLE, S., SUN, F. and HANDEL, M.A. (2009). Isolation and short-term culture of mouse spermatocytes for analysis of meiosis. Methods Mol Biol 558: 279-297.

MAHADEVAIAH, S.K., TURNER, J.M., BAUDAT, F., ROGAKOU, E.P., DE BOER, P., BLANCO-RODRIGUEZ, J., JASIN, M., KEENEY, S., BONNER, W.M. and BURGOYNE, P.S. (2001). Recombinational DNA double-strand breaks in mice precede synapsis. Nat Genet 27: 271-276.

MATULIS, S. and HANDEL, M.A. (2006). Spermatocyte responses in vitro to induced DNA damage. Mol Reprod Dev 73: 1061-1072.

MELO, J. and TOCZYSKI, D. (2002). A unified view of the DNA-damage checkpoint. Curr Opin Cell Biol 14: 237-245.

MISCHO, H.E., HEMMERICH, P., GROSSE, F. and ZHANG, S. (2005). Actinomycin $D$ induces histone gamma-H2AX foci and complex formation of gamma-H2AX with Ku70 and nuclear DNA helicase II. J Biol Chem 280: 9586-9594.

PAULL, T.T., ROGAKOU, E.P., YAMAZAKI, V., KIRCHGESSNER, C.U., GELLERT, M. and BONNER, W.M. (2000). A critical role for histone H2AX in recruitment of repair factors to nuclear foci after DNA damage. Curr Biol 10: 886-895.

PELLEGRINI, M., CLAPS, G., ORLOVA, V.V., BARRIOS, F., DOLCI, S., GEREMIA, R. ROSSI, P., ROSSI, G., ARNOLD, B., CHAVAKIS, T. et al., (2011). Targeted JAM-C deletion in germ cells by Spo11-controlled Cre recombinase. J Cell Sci124:91-99.

PELLEGRINI, M., DI SIENA, S., CLAPS, G., DI CESARE, S., DOLCI, S., ROSSI, P., GEREMIA, R. and GRIMALDI, P. (2010). Microgravity promotes differentiation and meiotic entry of postnatal mouse male germ cells. PLoS One 5: e9064.

ROSSI, R., LIDONNICI, M.R., SOZA, S., BIAMONTI, G. and MONTECUCCO, A (2006). The dispersal of replication proteins after Etoposide treatment requires the cooperation of Nbs1 with the ataxia telangiectasia Rad3-related/Chk1 pathway. Cancer Res 66: 1675-1683.

ROUSE, J. and JACKSON, S.P. (2002). Interfaces between the detection, signaling, and repair of DNA damage. Science 297: 547-551.

SHILOH, Y. (2003). ATM and related protein kinases: safeguarding genome integrity. Nat Rev Cancer 3: 155-168.

SHIOTANI, B. and ZOU, L. (2009). Single-stranded DNA orchestrates an ATM-to-ATR switch at DNA breaks. Mol Cell 33: 547-558.

TIBBETTS, R.S., BRUMBAUGH, K.M., WILLIAMS, J.M., SARKARIA, J.N., CLIBY, W.A., SHIEH, S.Y., TAYA, Y., PRIVES, C. and ABRAHAM, R.T. (1999). A role for ATR in the DNA damage-induced phosphorylation of p53. Genes Dev13: 152-157.

TURNER, J.M., MAHADEVAIAH, S.K., FERNANDEZ-CAPETILLO, O., NUSSENZWEIG, A., XU, X., DENG, C.X. and BURGOYNE, P.S. (2005). Silencing of unsynapsed meiotic chromosomes in the mouse. Nat Genet 37: 41-47.

WARD, I.M., MINN, K. and CHEN, J. (2004). UV-induced ataxia-telangiectasiamutated and Rad3-related (ATR) activation requires replication stress. J Biol Chem 279: 9677-9680.

WRIGHT, J.A., KEEGAN, K.S., HERENDEEN, D.R., BENTLEY, N.J., CARR, A.M. HOEKSTRA, M.F. and CONCANNON, P. (1998). Protein kinase mutants of human ATR increase sensitivity to UV and ionizing radiation and abrogate cell cycle checkpoint control. Proc Natl Acad Sci USA 95: 7445-7450.

YAZLOVITSKAYA, E.M. and PERSONS, D.L. (2003). Inhibition of cisplatin-induced ATR activity and enhanced sensitivity to cisplatin. Anticancer Res 23: 2275-2279.

ZHOU, B.B. and ELLEDGE, S.J. (2000). The DNA damage response: putting checkpoints in perspective. Nature 408: 433-4399. 


\section{Further Related Reading, published previously in the Int. J. Dev. Biol.}

The internal structure of embryonic gonads and testis development in Drosophila melanogaster requires scrib, Igl and dlg activity in the soma

Fani Papagiannouli

Int. J. Dev. Biol. (2013) 57: 25-34

Histone hyperacetylation during meiosis interferes with large-scale chromatin remodeling, axial chromatid condensation and sister chromatid separation in the mammalian oocyte

Feikun Yang, Claudia Baumann, Maria M. Viveiros and Rabindranath De La Fuente

Int. J. Dev. Biol. (2012) 56: 889-899

Comparative molecular portraits of human unfertilized oocytes and primordial germ cells at 10 weeks of gestation Ferdinand Diedrichs, Barbara Mlody, Peggy Matz, Heiko Fuchs, Lukas Chavez, Katharina Drewsand James Adjaye Int. J. Dev. Biol. (2012) 56: 789-797

Regulation of germ cell meiosis in the fetal ovary

Cassy M. Spiller, Josephine Bowles and Peter Koopman

Int. J. Dev. Biol. (2012) 56: 779-787

Study an egg today to make an embryo tomorrow Maurizio Zuccotti, Carlo Alberto Redi and Silvia Garagna Int. J. Dev. Biol. (2012) 56: 761-764

Germline stem cells and sex determination in Hydra Chiemi Nishimiya-Fujisawa and Satoru Kobayashi

Int. J. Dev. Biol. (2012) 56: 499-508

Impaired meiotic competence in putative primordial germ cells produced from mouse embryonic stem cells

Marianna Tedesco, Donatella Farini and Massimo De Felici

Int. J. Dev. Biol. (2011) 55: 215-222

A polymorphic, thrombospondin domain-containing lectin is an oocyte marker in Hydractinia: implications for germ cell specification and sex determination Brahim Mali, R. Cathriona Millane, Günter Plickert, Marcus Frohme and Uri Frank Int. J. Dev. Biol. (2011) 55: 103-108
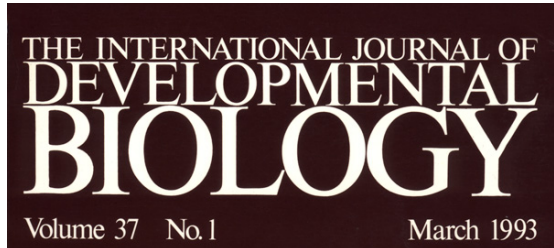

March 1993

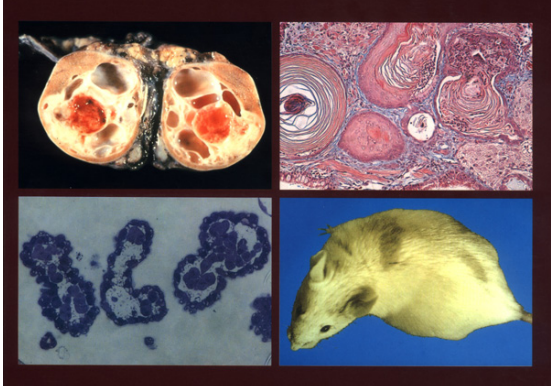

Developmental Aspects of Neoplasia
5 yr ISI Impact Factor $(2011)=2.959$

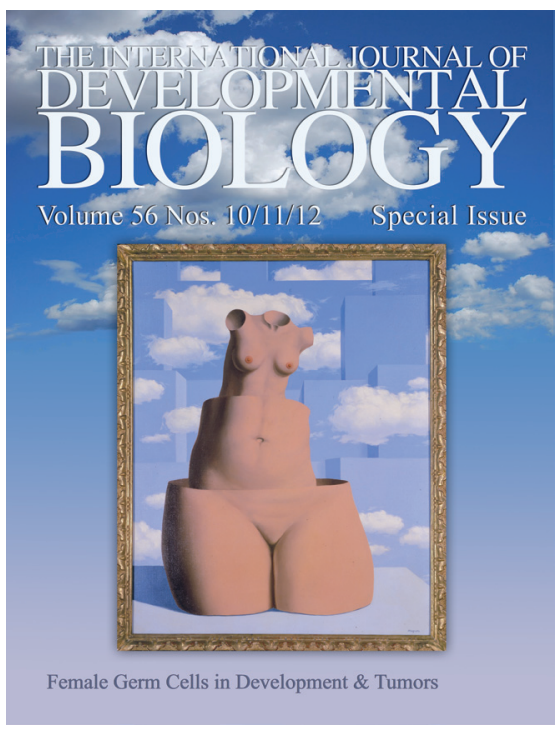

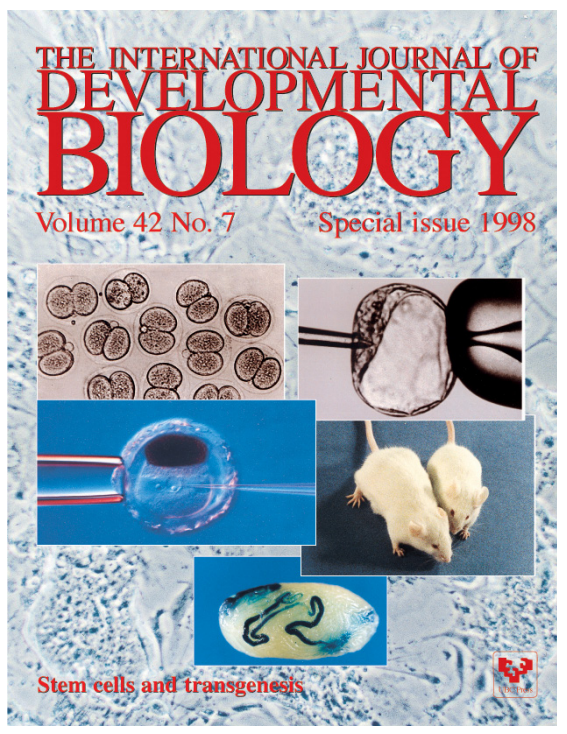

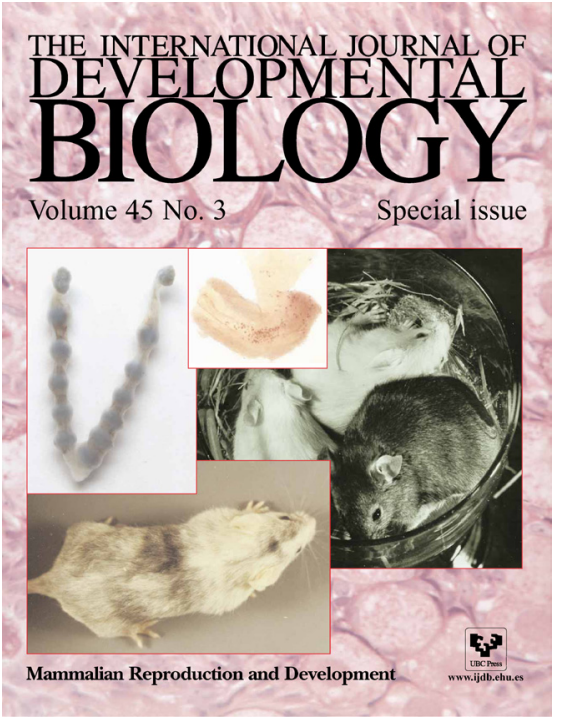

